\title{
GAMBARAN TANDA INFEKSI LOKAL LUKA POST SIRKUMSISI PADA USIA DEWASA DI KLINIK RATANCA MALANG
}

\author{
Vita Maryah Ardiyani ${ }^{1}$, Ani Sutriningsih ${ }^{2)}$, Supriyadi $^{3)}$ \\ 1),2)3) Fakultas Ilmu Kesehatan, Universitas Tribhuwana Tunggadewi \\ E-mail: vitamaryah@gmail.com
}

\begin{abstract}
Khitan or sirkumsisi is the act of cutting or completely wash out most cover foreskin of the penis based bealth reasons, culture or religious belief. The act of sirkumsisi going to leave scar tissue that need attention the handling and so does not carry infection. The Research aimed to identify marks infection of local injuries post sirkumsisi among those persons sirkumsisi in adult at ratanca malang clinic. The research uses observational descriptive design. The population all participants who register as many as 20 sirkumsisi operation of a person taken in total the sampling method.V ariable free consisting of pain, reddish, heat, swollen, and the existence of the pus to wounds post sirkumsisi 3rd day .Data analyzed a sort of descriptive set. The results of the study or the sign of a local infection consisting of a reddish (95\%), pain (95\%), heat (85\%), swollen (85\%), and the absence of pus (80\%) in about wound post sirkumsisi . Further Research said must be implemented to observe sirkumsisi wound among respondents adults in a longer period of time and measuring factors influencing the healing of injured sirkumsi.
\end{abstract}

Keywords: The signs of infection; adult sirkumsisi.

\begin{abstract}
ABSTRAK
Khitan atau sirkumsisi adalah tindakan memotong atau menghilangkan sebagian atau seluruhkulit penutup depan (kulup) dari penis yang didasarkan alasan kesehatan, budaya atau keyakinan agama. Tindakan sirkumsisi akan meninggalkan bekas luka yang perlu diperhatikan penanganannya sehingga tidak menimbulkan infeksi. Penelitian bertujuan mengidentifikasi tanda infeksi lokal luka post sirkumsisi pada peserta sirkumsisi dewasa di Klinik Ratanca Malang. Desain penelitian menggunakan deskriptif observasional. Populasi seluruh peserta yang mendaftar operasi sirkumsisi sebanyak 20 orang yang diambil secara total sampling. Variabel bebas terdiri dari nyeri, kemerahan, panas, bengkak, dan adanya nanah pada luka post sirkumsisi hari ke-3. Data dianalisis secara deskriptif. Hasil penelitian didapatkan tanda infeksi lokal terdiri dari kemerahan (95\%), nyeri (95\%), panas (85\%), bengkak (85\%), dan tidak adanya nanah (80\%) pada sekitar luka post sirkumsisi. Penelitian
\end{abstract}


lebih lanjut perlu dilaksanakan untuk mengobservasi luka sirkumsisi pada responden dewasa dalam rentang waktu yang lebih lama dan mengukur faktor-faktor yang mempengaruhi penyembuhan luka sirkumsi.

Kata Kunci: Infeksi local; sirkumsisi; dewasa.

\section{PENDAHULUAN}

Sirkumsisi adalah tindakan pembuangan sebagian/ seluruh kulup (prepusium) penis untuk tujuan tertentu. Tindakan sirkumsisi dilakukan untuk alasan kesehatan, budaya, maupun perintah agama. Sirkumsisi diharapkan mengurangi masalah akibat kondisi medis tertentu. Sirkumsisi sangat menguntungkan bagi kesehatan. Banyak manfaat sirkumsisi antara lain mencegah infeksi saluran kemih, membuat penis menjadi bersih, mencegah penularan HIV, serta mengurangi resiko terkena karsinoma penis (Prasetyo, 2018).

Angka sirkumsisi di dunia mencapai 2533\% populasi laki-laki. Di Amerika Serikat angka sirkumsisi mencapai 70\%, di Inggris $6 \%$ dan di Nigeria tingkat sirkumsi diperkirakan $87 \%$. Secara medis tidak ada batasan usia untuk melakasanakan sirkumsisi. Di Indonesia sirkumsisi sering dilakukan pada usia 6-12 tahun dan umumya dilakukan oleh anak laki laki mencapai angka 85\% atau sekitar 8,7 juta jiwa (WHO, 2010).
Tindakan sirkumsisi merupakan tindakan bedah yang meninggalkan luka setelah prosedur pelakansanaanya sehingga memerlukan prosedur perawatan khusus untuk mencegah terjadinya infeksi dan gangguan aktifitas pasien prosedur sirkumsisi. Setelah seseorang melaksanakan sirkumsisi, akan membutuhkan waktu antara satu minggu sampai sepuluh hari agar bekas luka kering sehingga menutup dengan sempurna. Istirahat sangat diperlukan agar tidak bengkak berlebihan (Mursyida, 2019).

Perawatan luka sirkumsisi terkontaminasi menyebabkan komplikasi sirkumsisi berupa perdarahan, infeksi serta komplikasi obat anastesi. Infeksi disebabkan oleh bakteri bukan satusatunya penyebab luka sulit sembuh. Pada kasus penderita immunocompromised, luka sirkumsisi terinfeksi oleh jamur maupun virus. Infeksi dan luka sirkumsisi sulit sembuh disebabkan defisiensi zat gizi. Vitamin A, B, C, D, kalsium, seng, magnesium, serta zat besi adalah zat gizi mikro untuk proses penyembuhan luka. 
Zat gizi mikro membantu tubuh untuk meregenerasi sel serta jaringan rusak, menurunkan tingkat peradangan, menjaga sistem kekebalan tubuh tetap normal, serta menguatkan jaringan yang baru diperbaiki (Prasetyo, 2018).

Terdapat beberapa metode sirkumsisi yaitu konvensional (teknik dorsumsisi) dan laser (electrocauter). Metode konvensional adalah metode standard sesuai standard medis sehingga meningkatkan keberhasilan sirkumsisi. Metode electrocauter menggunakan alat menyerupai pisau dengan ujung kawat. Kelebihan metode electrocautermampu meminimalkan perdarahan pasca sirkumsisi (Mursyida, 2019).

Sirkumsisi usia dewasa muda di Indonesia minim dilakukan karena umumnya dilakukan pada usia anak. Kecuali terdapat kondisi medis tertentu sirkumsi diindikasikan pada berbagai rentang usia. Berdasarkan fakta di atas,perlu adanya gambaran tanda infeksi lokal post sirkumsisi pada usia dewasa sehingga dapat perhatikan temuan sirkumsisi pada usia dewasa.

\section{METODE PENELITIAN}

Penelitian menggunakan metode deskriptif observasional dengan menjabarkan tanda infeksi lokal yaitu kemerahan, nyeri, panas, bengkak dan adanya nanah. Populasi dalam penelitian adalah seluruh peserta sirkumsisi dewasa pada program sirkumsisi gratis di Klinik Ratanca Malang sebanyak 20 orang yang diambil secara total sampling.Sebelumnya peneliti memberikan penjelasan sebelum penelitian dan responden mengisi lembar persetujuan penelitian.

Variabel bebas terdiri dari nyeri, kemerahan, panas, bengkak, dan adanya nanah pada luka post sirkumsisi hari ke-3. Data dianalisis secara deskriptif. Instrumen penelitian menggunakan lembar observasi berisi tanda infeksi lokal yang diisi oleh peneliti dengan cara pengamatan secara visual tanda infeksi lokal post sirkumsisi hari ke-3 pada saat responden melakukan kontrol luka. Selanjutnya data dianalisis secara deskriptif dan disajikan dalam bentuk tabel distribusi frekuensi.

\section{HASIL}

Penelitian mengenai gambaran tanda infeksi lokal post sirkumsisi pada usia dewasa telah dilakukan pada kegiatan khitan masal dewasadi Klinik Ratanca Malang dengan melakukan pengamatan secara visual tanda infeksi lokal post sirkumsisi hari ke-3 pada saat responden 
melakukan kontrol luka yaitu sebanyak 20 orang.

Berdasarkan tabel 1 didapatkan hasil bahwa hampir separuhberusia 22 dan 24 tahun (35\%), lebih dari separuh responden beragama Kristen (55\%), seluruh responden tidak mempunyai riwayat DM (100)\%, seluruh responden mendapatkan antibiotik profilaksis $(100 \%)$, seluruh responden mandi sebelum sirkumsisi $(100) \%$, dan seluruh responden dilakukan skiren sebelum sirkumsisi $(100) \%$.

Tabel 1. Distribusi Frekuensi berdasarkan Karakteristik UmumResponden di Klinik Ratanca Malang

\begin{tabular}{lll}
\hline \multicolumn{1}{c}{ Karakteristik } & $\mathbf{f}$ & $\mathbf{( \% )}$ \\
\hline Usia & & \\
21 Tahun & 3 & 15 \\
22 Tahun & 7 & 35 \\
23 Tahun & 3 & 15 \\
24 Tahun & 7 & 35 \\
\hline
\end{tabular}

\begin{tabular}{lcc}
\hline Agama & & \\
Kristen & 11 & 55 \\
$\quad$ Katolik & 9 & 45 \\
\hline Riwayat DM & & \\
$\quad$ Ada & 0 & 0 \\
$\quad$ Tidak & 20 & 100 \\
\hline $\begin{array}{l}\text { Antibiotika } \\
\text { Profilaksis }\end{array}$ & & \\
Ya & 20 & 100 \\
$\quad$ Tidak & 0 & 0 \\
\hline Mandi sebelum & & \\
Sirkumsisi & & \\
Ya & 20 & 100 \\
Tidak & 0 & 0 \\
\hline Skiren & & \\
Ya & 20 & 100 \\
Tidak & 0 & 0 \\
\hline \multicolumn{1}{r}{ Total } & $\mathbf{2 0}$ & $\mathbf{1 0 0}$ \\
\hline
\end{tabular}

Berdasarkan Tabel 2 didapatkan hasil bahwa hampir seluruh responden mengalami kemerahan pada luka sebanyak (95\%), hampir seluruh responden mengalami nyeri (95\%), hampir seluruhnya merasakan panas pada luka $(85 \%)$, responden yang mengalami bengkak pada luka hampir seluruhnya (85\%), hampir semua responden lukanya tidak bernanah $(80 \%)$.

Tabel.2. Distribusi Frekuensi berdasarkan Tanda Infeksi LokalPost Sirkumsisi di Klinik Ratanca Malang

\begin{tabular}{ccc}
\hline $\begin{array}{c}\text { Tanda Infeksi } \\
\text { Lokal }\end{array}$ & $\mathbf{f}$ & $\mathbf{( \% )}$ \\
\hline Kemerahan & & \\
Ada & 19 & 95 \\
Tidak & 1 & 5 \\
\hline Nyeri & & \\
Ada & 19 & 95 \\
Tidak & 1 & 5 \\
\hline Panas & & \\
Ada & 17 & 85 \\
Tidak & 3 & 15 \\
\hline Bengkak & & \\
Ada & 17 & 85 \\
Tidak & 3 & 15 \\
\hline Nanah & & \\
Ada & 4 & 20 \\
Tidak & 16 & 80 \\
\hline Total & $\mathbf{2 0}$ & $\mathbf{1 0 0}$ \\
\hline
\end{tabular}

\section{PEMBAHASAN}

Berdasarkan hasil penelitian didapatkan hampir seluruh responden mengalami tanda infeksi lokal post sirkumsisi yaitu kemerahan, nyeri, panas, dan bengkak sementara adanya nanah ditemukan hanya sebagian kecil. Persentase tanda infeksi 
lokal dalam penelitian ini cukup tinggi jika dibandingkan dengan standar Center for Diseases Control and Prevention tentang infeksi luka operasi pada pasien post operasi yaitu $<2 \%$. Hal serupa ditemukan pada penelitian lainnya yaitu (Elnur AI, 2012) sebesar 8\% dan (Saxena A, 2013) sebesar $12.1 \%$.

Tingginya angka kejadian infeksi luka operasi pasca operasi bersih pada penelitian ini kemungkinan dipengaruhi olehfaktor teknik pembedahan diantaranya tindakan asepsis dan antisepsis yang seharusnya dilakukan dengan mutlak serta tidak dipertahankannya suasana asepsis pada saat berlangsungnya pembedahan (Sjamsuhidajat, 1997). Kemungkinan lain penyebab tingginya persentase tanda infeksi lokal dalam penelitian ini adalah sterilitas dari ruang dan instrumen operasi, kontaminasi daripetugas kesehatan di klinik serta tindakan aseptik dan antiseptik yang inadekuat pada responden dan juga tim bedah.

Hasil penelitian menunjukkan seluruh responden penelitian berada pada rentang usia dewasa yaitu pada rentang 21-24 tahun. Rentang usia dewasa berhubungan terhadap proses penyembuhan infeksi pada faktor penyembuhan luka.Penuaan berhubungan dengan perubahan fungsi dan struktur yang menyebabkan jaringan kulit dan subkutis lebih rentan terhadap infeksi. Perubahan ini tidak dapat dihentikan namun pengaruhnya dapat dikurangi dengan teknik bedah yang baik dan antibiotik profilaksis (Cabrera rafael heruzo, 2004) Berdasarkan Tabel 2 seluruh responden telah mendapatkan antibiotik profilaksis sebelum sirkumsisi.

Hasil penelitian Aykac, et al (2016) menyatakan bahwa proses penyembuhan luka sirkumsisi dipengaruhi oleh usia, Proses penyembuhan luka sisrkumsisi pada responden yang berusia 0-6 tahun terbukti lebih pendek proses penyembuhannya dibandingkan dengan responden yang berusia 7-16 tahun. Dimana sirkumsisi umumnya dilakukan pada bayi baru lahir di Negara barat dan biasa dilakukan pada usia anak-anak di Negara timur serta dilakukan pada orang dewasa di Afrika.Hasil studi lain menyebutkan bahwa tindakan sirkumsisi yang dilakukan pada usia neonatal atau bayi mempunyai komplikasi yang relatif lebih rendah dibandingkan dengan anak yang mempunyai usia lebih tua (Al Mutairi HM, 2018).

Perkiraan proporsi laki-laki diseluruh dunia yang disirkumsisi bervariasi dari 1/6 
hingga 1/3. Organisasi Kesehatan Dunia (WHO) memperkirakan bahwa secara global, 30\% dari laki-laki berusia 15 tahun ke atas disunat, dengan hampir 70\%-nya merupakan Muslim (Erika, rahma, 2020). Penelitian yang dilakukan oleh Anwer, Iftikhar dan Ansari (2017) meyebutkan bahwa tindakan sirkumsisi merupakan suatu tradisi yang biasa dilakukan oleh kaum Yahudi dan Muslim selain itu juga karena alasan keagamaan. Hampir dua pertiga dari pria yang sirkumsisi di seluruh dunia adalah Muslim. Jika dihubungkan dengan hasil penelitian dimana pada umumnya yang melaksanakan sirkumsisi adalah seorang muslim.Fenomena baru didapatkan dari hasil penelitian yaitu seluruh responden beragama Katolik dan Kristen. Berdasarkan hasil wawancara alasan responden melakukan sirkumsisi sebagian besar untuk alasan kesehatan.

Berdasarkan hasil penelitian tanda infeksi pada responden sirkumsisi meliputi hampir seluruh repoden mengalami kemerahan, nyeri, panas pada sekitar luka dan bengkak. Terdapat sebagian kecil respoden mengalami luka bernanah. Tanda-tanda infeksi pada hari ke-3 post sirkumsisi pada umumnya berada pada tahap penyembuhan luka fase inflamasi. Fase ini dimulai sejak terjadinya luka sampai hari kelima. Segera setelah terjadinya luka, pembuluh darah yang putus mengalami konstriksi danretraksi disertai reaksi hemostasis karena agregasi trombosit yang bersama jala fibrin membekukan darah. Komponen hemostasis ini akan melepaskan dan mengaktifkan sitokin yang meliputi Epidermal Growth Factor (EGF), Insulin-like Growth Factor(IGF), Plateled-derived Growth Factor (PDGF) danTransforming Growth Factor beta (TGF- $\beta$ ) yang berperan untuk terjadinya hemotaksis netrofil, makrofag, sel mast, sel endotelial dan fibroblas.Keadaan ini disebut fase inflamasi. Pada fase ini kemudian terjadi vasodilatasi danakumulasi leukosit Polymorphonuclear (PMN). Agregat trombosit akan mengeluarkan mediator inflamasi Transforming Growth Factorbeta 1 (TGF 1) yang juga dikeluarkan oleh makrofag. Adanya TGF 1 akan mengaktivasi fibroblas untuk mensintesis kolagen (Sihombing, 2014).

Proses penyembuhan luka juga di pengaruhi faktor internal seseorang. Perfusi lokal sangat mempengaruhi timbulnya infeksi, terbukti pasien dengan gangguan vaskuler perifer cenderung mengalami infeksi pada tungkai. Penurunan perfusi jaringan mampu memicu pertumbuhan kuman penyebab 
infeksi, hal ini terjadi karena perfusi yang tidak adekuat menyebabkan penurunan kadar oksigen jaringan. Pada keadaan syok perfusi jaringan juga menurun sehingga mempengaruhi infeksi dimana hanya sedikit kuman yang dibutuhkan untuk menimbulkan infeksisegera setelah syok, untuk mengatasi efek ini tekanan oksigen arterial harus dirubah menjadi kadar oksigen subkutan yang adekuat, yang kemudian bersama-sama dengan perfusi yang adekuat akan menghasilkan perlindungan lokal, sehingga dibutuhkan jumlah bakteri yang lebih banyak untuk dapat menimbulkan suatu infeksi (Cabrera rafael heruzo, 2004).

Pelakasanaan metode sirkumsisi pada responden adalah metode manual. Teknik sirkumsisi dengan cara menjepit prepusium secara melintang pada sumbu panjang penis, kemudian memotongnya, insisi dapat dilakukan pada bagian proximal atau distaldari klem tersebut (Shofiyah, 2017) . Sejalan dengan hasil penelitian Shofiyah (2017) menunjukkan tidak terdapat perbedaan lama penyembuhan antara teknik manual dengan teknik laser. Penelitian lain menyebutkan luka sayatan yang dihasilkan dari metode sirkumsisi manual atau tradisional mempunyai beberapa kekurangan yaitu waktu pelaksanaan tindakan cenderung lama, proses menjahit luka memakan banyak waktu, bekas luka sayatan mudah menimbulkan infeksi, metode ini juga menimbulkan efek samping seperti hematoma dan model penis yang kurang bagus (Huo Z C, 2017).

Penelitian lain juga mengungkapkan bahwa berbagai masalah yang diakibatkan dari tindakan sirkumsisi antaralain; perdarahan, infeksi, buman errormampu menyebabkan cedera uretra, fistula uretra, eksisi sebagian atau seluruh glans penis, nekrosis dan ablasi penuh pada penis dan lain sebagainya (Demashevskiy JA, 2016).

\section{KESIMPULAN}

Hampir seluruh responden mengalami tanda-tanda infeksi seperti kemerahan, nyeri, panas, dan bengkak dan sebagian kecil reponden mengalami luka bernanah. Pelaksanann sirkumsisi pada usia dewasa perlu memperhatikan riwayat diabetes mellitus, pemberian antibiotik profilasksis yangn berpengaruh pada proses peyembuhan luka post sirkusisi.

\section{SARAN}

Perlu dilaksanakan penelitian lebih lanjut dan mengobservasi luka sirkumsisi pada responden dewasa dalam rentang waktu yang lebih lama dan mengukur faktor 
yang mempengaruhi penyembuhan luka sirkumsisi.Pengkajian riwayat peserta sirkumsi dewasa perlu di kaji secara

\section{REFERENSI}

Al Mutairi HM, A. A.-S.-S. (2018). Knowledge and attitude of parent toward their son's circumcision at King Saud Hospital in Unaizah City. International Journal Of Medical Research Professional, 34-39.

Cabrera rafael heruzo, J. D. (2004). Surgical site infection of traumatologic inpatient( devided in two sub-cohort, study and validation): Modifable determinans adn potential benefit. Journal of Cilnical Research \& Bioethics, 163-169.

Demashevskiy JA, D. A. (2016). Ethics Pertaining to the Legalities Of Male Routine Infant Circumsicion and Surrogate Consent to Nonterapuetic Surgery. Journal Of Clinical Research \& Bioethic, V01 7:4.

Elnur AI, Y. M. (2012). Prevalence and Predictor Of Wound Infection in Elective Clean and Clean/Contaminated Surgery in Khartoum Teaching Hospital, Sudan. International Jurnal Infection Control , 1010.

Huo Z C, L. G. (2017). Use Of A Disposable Circumcision Suture Device Versus Conventional Circumsicion: A Systematic Review And Meta Anaysis. Asian Journal of Andrology, 362-367.

Mursyida, E. (2019). Sirkumsisi Pada Anak Di KelurahanArgowisata mendalam untuk mencegah kendala dalam penyembuhan luka post sirkumsisi

Kecamatan Rumbai Pekanbaru. Jurnal Pengabdian Masyarakat Multidisiplin, 43-49.

Prasetyo, B. (2018). Asupan Seng dan Penyembuhan Luka Sirkumsisi. Journal OF Nutrition and Health Volume 6 n0 2.

Prevention, C. f. (2014). Surgical Site Infection (SSI) Event. Retrieved september friday, 2020, from www.cdc.gov:

http://www.cdc.gov/nhsn/pdfs/psc manual/9pscssicurrent.pdf

Saxena A, S. M. (2013). Surgikal Site Infection Among Postoperative Patient Of Tertiary care Centre in Central India- A Prospective Study. Asian Jurnal Biomed Pharm Sci , 3(17):41-4.

Shofiyah, S. (2017). Perbedaan Lama Penyembuban Luka Antara Teknis Sirkumsisi Laser dengn Manual di Wilayah Kerja Puskesmas Gunungsari Kecamatan Baureno Kabupaten Bojonegoro. Retrieved August Monday, 2020, from

Www.Repository.Umla.Ac.Id/604/1

Sihombing, M. A. (2014). Infeksi Luka Profesi. Universitas Sriwijaya E Journal . Sjamsuhidajat. (1997). Buku Ajar Ilmu Bedah. Jakarta: EGC.

WHO. (2010, january). Neonatal and Child Male Circutition : a global review. Retrieved july friday, 2020, from www.who.int: hhtp://www.who.int/hiv/pub 